\title{
Studies on the flora of Yemen: Flora of Kharab AlMarashi, AlJawf, Republic of Yemen
}

\author{
Dahmash AMA \\ Biology Department, Faculty of Science, Sana'a University, Yemen
}

Received: 11 Februry 2015 / Accepted: 21 March 2015

email: Abdudahmash@yahoo.com

\begin{abstract}
The present study deals with the floristic analysis of Karab AlMarashi, Al Jawf, Yemen. Eighty six species belong to 67 genera and 36 families of the vascular plants have been recorded. The dicots are represented by 81 species, while the monocots are represented by 5 species. The family Asteraceae had the highest contributions followed by Asclepiadaceae, Solanaceae, Malvaceae, Apiaceae, Zygophyllaceae, Euphorbiaceae and Lamiaceae. Life form spectra are highly represented by chamaephytes followed by phanerophytes, therophytes, hemicryptophytes and cryptophytes. The pluriregionals species are the highest, followed by the mono-regionals species, while the bi-regionals species were the lowest. The present results proved that the flora of Kharab AlMarashi is species rich and diverse. The generic index is 1.3. Acacia is the largest recorded genus in Kharab AlMarashi.
\end{abstract}

Keywords: Chorotype, Floristic analysis, Life form, Yemen, Wadis

\section{Introduction}

Flora of Yemen is rich and diverse, species diversity is a result of considerable climatic change in former period, which enable different species to survive, in the different habitats (Ministry of water and Environmental, 2010). Recent studies reported that there are about 2838 plant species belong 1068 genera and 179 families in Yemen; of these 2602 are native, 129 cultivated and 107 introduced (AlKhulidi, 1989; 2000; 2006; 2013).

Yemen is rich in endemic plants, which are estimated to be 608 , of which 307 endemic species in Socotra (Al-Khulidi 2013). Agriculture and animal husbandry are the main activities of the population. The AlJawf can be an agricultural region as the agricultural crops constitute $(4.9 \%)$ of the total agricultural production in the Republic of Yemen, and the most important agricultural crops are cereals, vegetables, fruits and fodder. It is important place for and fertile valleys for Agriculture vegetables and grew wheat, barley and fruits. The terrain of AlJawf is often plain, as it interferes with the Rub $\mathrm{Al}$ Khali desert, and 
characterized by a desert climate. Floristically, Kharab AlMarashi is one of the promising regions in Yemen with wide habitat types and poor knowledge on its flora. The aim of this study is to provide a description of the floristic composition and life form spectrum, and to prepare an annotated checklist of the flora of the studied area as a step towards understanding the flora of Yemen as a whole.

\section{Study area}

Yemen Republic extends over approximately $7^{\circ}$ degrees of latitude. From $12^{\circ}$ to $19^{\circ}$ in the north and between 42 to 53 E. Longitude (Fig. 1). Al-Jawf located at latitude $16^{\circ} 47^{\prime}$ north and longitude $45^{\circ}$ $31^{\prime}$ east. Total area covers about 393.4 square kilometers. Al-Jawf located to the north east of the capital Sana'a, and away from it about 143 kilometers. It is located north Sa'ada province, the Empty Quarter desert from the east, parts of the provinces of Marib and Sana'a from the south and
Amran province from the west (Fig. 1).

Al-Jawf was the home of the ancient Maeen kingdom. The population of the governorate accounted for $(2.3 \%)$ of the total population of the Yemen Republic, and the number of its districts are twelve districts namely: Brat alanan, Alhazm, Alhumidates, Kab and Alshaf, Krab Almrashi, Alkhlq, Ragoza, Al-zaher (AlJawf)), Alghil, Almuton, Almasloband Almatamah. Hazm city is the center of the AlJawf.. Karaba Almarashi desert is located in the Eastern desert of Yemen. It is characterized by many mountains which are either single or connected with mountains series as example gable tan in wadi Amranh (Results of the general census of population and housing facilities, 2004).

Climate of the area is tropical and arid. Air temperature maximum ranged from 18.2 to $35^{\circ} \mathrm{C}$. The wind speed ranged between 11 and $22.5 \mathrm{~K} / \mathrm{h}$. The rainfalls were rarely in most months recorded in February, April and July respectively. The annual rainfall was $40 \mathrm{~mm}$ (Table1).

Table 1. Monthly average for eight years ( from 2001 to 2008) Climate data obtained from Statistical Department Central planning Organization, Prime Minister's office, Sana'a, Yemen

\begin{tabular}{|c|c|c|c|c|c|c|}
\hline Month & $\begin{array}{l}\text { Temp }{ }^{\circ} \mathrm{C} \\
\operatorname{Max}\end{array}$ & Min & Mean & $\begin{array}{l}\text { Relative } \\
\text { humidity\% }\end{array}$ & $\begin{array}{l}\text { Wind speed } \\
\mathrm{Km} \mathrm{h}^{-1}\end{array}$ & $\begin{array}{l}\text { Rainfall } \\
\mathrm{mm}\end{array}$ \\
\hline January & 20.3 & 13.7 & 17.8 & 25 & 13.6 & 0.0 \\
\hline February & 21.3 & 13.8 & 18.0 & 23 & 11.0 & 11.5 \\
\hline March & 27.1 & 15.4 & 22.9 & 21 & 11.0 & 0.0 \\
\hline April & 29.5 & 24.0 & 27.1 & 23 & 14.5 & 26.0 \\
\hline May & 34.1 & 30.2 & 32.2 & 28 & 16.5 & 0.0 \\
\hline June & 33.0 & 29.8 & 31.6 & 26 & 19.3 & 0.0 \\
\hline July & 33.5 & 29.9 & 32.3 & 25 & 21.9 & 2.5 \\
\hline August & 35.0 & 31.0 & 32.9 & 25 & 22.5 & 0.0 \\
\hline September & 33.9 & 29.7 & 31.8 & 22 & 14.7 & 0.0 \\
\hline October & 29.4 & 22.1 & 26.3 & 33 & 13.4 & 0.0 \\
\hline November & 23.7 & 17.7 & 20.4 & 27 & 12.5 & 0.0 \\
\hline December & 18.2 & 12.7 & 15.9 & 16 & 12.3 & 0.0 \\
\hline Total annual & & & & & & 40.0 \\
\hline
\end{tabular}

\section{Materials and Methods}

Field survey was carried out through several trips during 2011/2012. In each trip, plant samples were collected from different habitats of Kharab AlMarashi, AlJawf.

The study area included many wadies namely Alnel, Almaranh, masuad, dahmah, Nahyan, Alsll 
and Alsakamah. The plant specimens were collected and pressed as according Fosberg (1965) and Womberley (1981).

Plants with large fleshy leaves and plants which have large leaves and inflorescence have been photographed and the inflorescence has been cut and representative, sections of the stalk, branch, flower and fruit were placed in the press. The plant specimens were pressed in the field using newspaper and woody presser. The specimens were transported to the laboratory to complete the drying process.

When the specimens were completely dried, each individual specimen was mounted on a herbarium sheet with size $(16$ inch $\times 12$ inch $)$. For each species collected at least three dried specimen were mounted on herbarium sheet with label includes: the scientific name, family name, locality, altitude, GPS information (altitude, latitudes and longitudes), collecting number, collector name, collecting date, landscape and so on.

Arrangement of the families in the present work was alphabetically, within each family the genera and species were arranged alphabetically. The species was identified according to (Migahid, 1978; Chaudhary, 1989; 1999; 2000; 2001a; b \& c; Chaudhary and Revri, 1983); Tackholm, 1974; Alkhulidi, 2000 \& 2013; Boulos, 2002; Collenette, 1999; Wood, 1997; Omar, 2000; Zoghet and Al Alsheikh, 1999)

The life form categories were identified according to Raunkiaer's system of classification (Raunkier, 1937). A chorological analysis of the floristic categories of species was made to assign the recorded species to world geographical groups, according to (Zohary, 1973; Wickens, 1978).

\section{Results}

The recorded species, families, life forms and chorotypes are listed in appendix. A total of 86 species belonging to 67 genera and 36 families are recorded. The family Asteraceae have the highest contribution to the total flora (11 sp., 12.8\%) followed by Fabaceae (7 sp., 8.2\%), Solanaceae (6 sp., 6.9\%), Asclepiadaceae (5 sp., 5.8\%), Euphorbiaceae, Lamiaceae, Malvaceae, Zygophyllaceae (4 sp., 4.7\% for each), and Amaranthaceae, Caesalpiniaceae, Capparaceae, Cucurbitaceae (3 sp., 3.5\% for each) (Fig. 2). Two families were represented by two species and twenty two families were represented by one species.

The life forms spectra of the vegetation in the study area indicated that, chamaephytes had the highest contribution in the study area $(41.9 \%$ of the total recorded species) followed by the phanerophytes (25.6\%), therophytes (18.6\%), hemicryptophytes (8.2\%), and cryptophytes (4.7\%), while parasites were the lowest with $1.2 \%$ (Fig. 3).

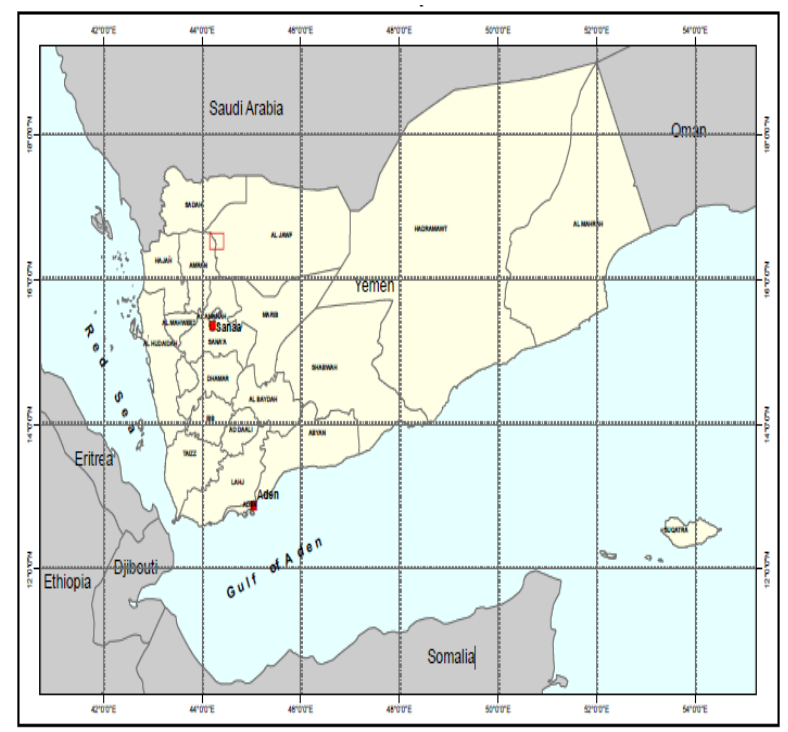

Fig. 1 Map of Yemen showing the study area.

Data of the chorological analysis are presented in Table 2. Thirty species constitute $34.9 \%$ of the total recorded species are mono regional, of which 12 species which constitute $13.9 \%$ are being native to the Sudano-Zambezian phytocharia. In addition to the above there are other elements of monoregional such as Saharo-Arabian-SudanoZambezian (9 sp., 10.5\%), Saharo-Arabian and Sudano (4 sp., 4.7\%), Sudano and Saharo-Arabian elements (2 sp., 2.3\% for each) and Saharo-Sindian (1 species., 1.2\%).

Bi-regionals elements are represented by 20 species (23.3\% of the total number of species). Of these the Sahrao-Sindian and Sudano-Zambezian elements together are represented by 9 species which constitute $10.5 \%$ of total species followed by 
Irano-turenian and Mediterranean elements together are represented by 4 species which constitute $4.7 \%$ of the total species.

Saharo-Sindian and Irano-Turanian elements together are represented by 3 species which constitute 3.5\%, of the total species, Mediterranean and Saharo -Arabian comprise two species which constitute $1.1 \%$ of the total species, Mediterranean, Saharo-Arabian and Sudano-Zambezian element together is represented (one species, 1.1\%) and Saharo-Arabian and Irano-Turanian (one species, $1.1 \%)$.

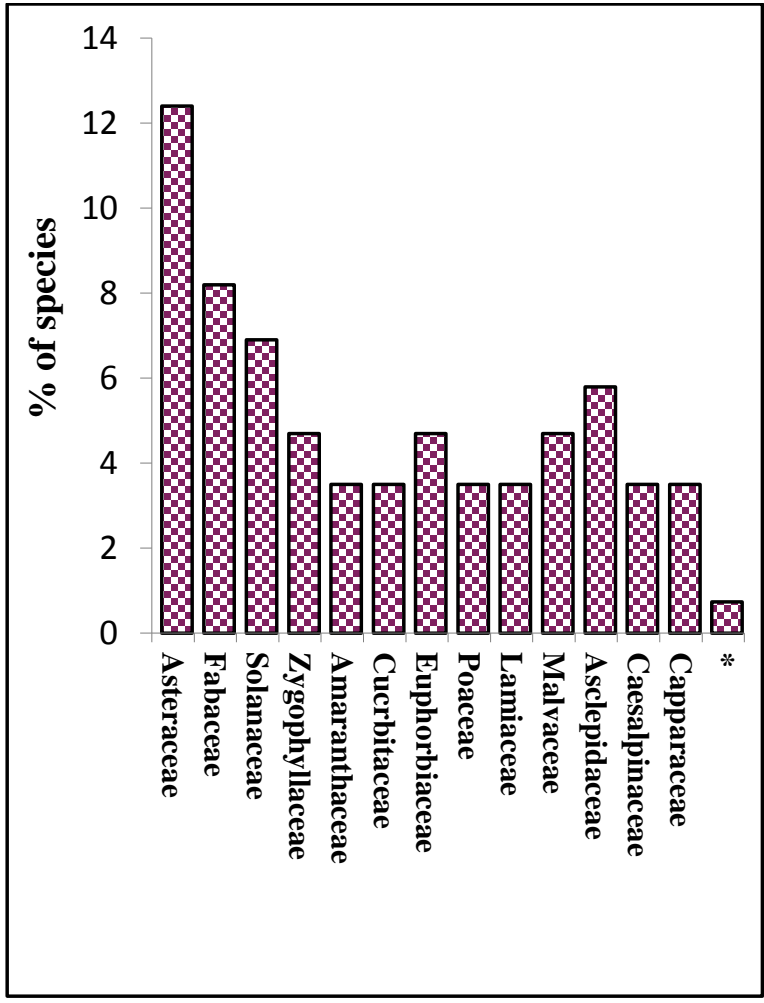

Fig. 2 Shows the percentages of plant species in each of the 36 families recorded in the study area (Kharab AlMarashi). ${ }^{*}=24$ families are represented by one or two species.

Meanwhile pluri-reginoals elements are presented by 36 species constitute $41.9 \%$ of the total species. Tropical and Cosmopolitan of the pluri-regionals were represented by $(7$ species, $8.1 \%$ for each) of the total species, followed by Pantropical (4 species, 2.3\%), Saharo-Sindian,
Sudano-Zambezian and Irano-Turanian, SindianSaharo+Sudano-Zambezian and Irano-Turanian were represented by ( 3 species, 3.5\% for each) of the total species. Most of the plu-regionals elements are comprised from Mediterranean and Irano-Turanian regions. Also, the Phytogeographical analysis of plant species in the study area showed that 3 species (3.5\%) are endemic to the flora of Yemen (Table 2).

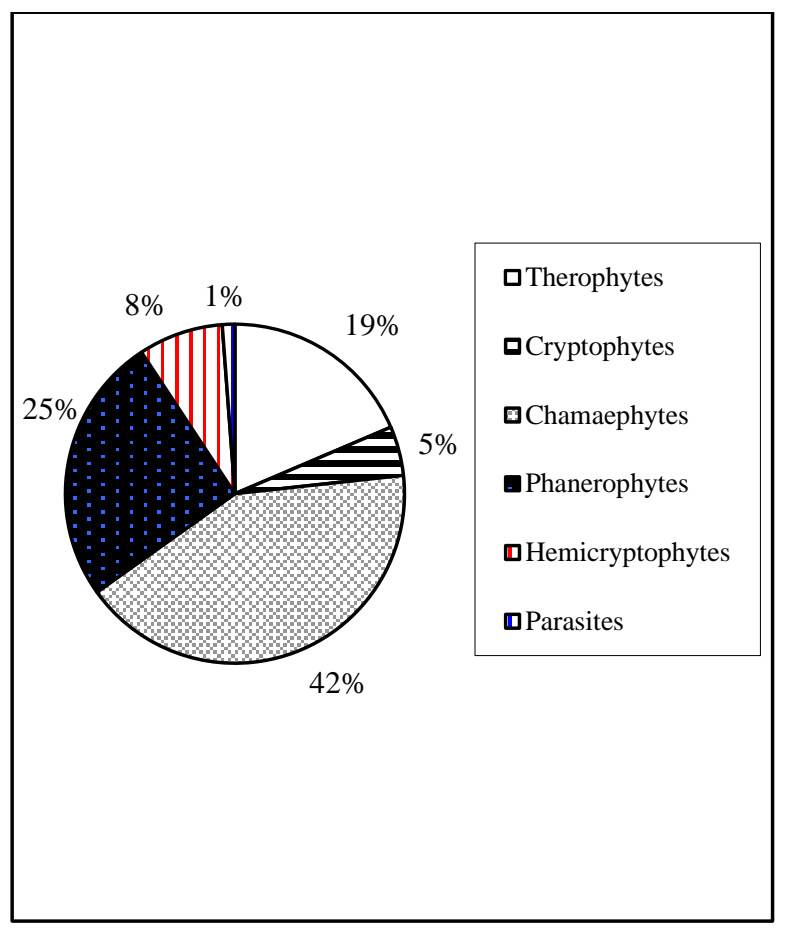

Fig. 3 Proportionate representation of life forms in the flora of Kharab AlMarashi. (as a percentage of 86 plant species).

\section{Discussion}

Despite of the intensive floristic studies in the different regions of Yemen, the flora of Arabia and Yemen, are considered to be the least known regions floristically, comparing with the other neighboring countries (Miller and Nyberg, 1991). The same words can be said about the flora of Kharab AlMarashi, comparing with the other governorates of Yemen.

Results revealed that, flora of Yemen is relatively rich and diverse, comparing with the 
others arid and semi-arid regions in Yemen, such as: Ibb, Taiz, Al-Mahweet, Hadhramout, AlMahrah and Shabwa. A total number of the vascular plant recorded from the studied area is 86 species (species and intraspecific species) related to 67 genera and 36 families. These numbers are relatively low compared with those recorded from other regions or governorates of Yemen, even their climates are humid and arid. If we have a look at the previous results of the floristic composition in other governorates of Yemen we can note that.

Table 2. Phytogeographical analysis of plant species the study area ( Kharab AlMarashi ) Al Jawf, Yemen. For abbreviation see appendix.

\begin{tabular}{ll}
\hline Chorotype & Species \\
& Number $\quad(\%)$ \\
\hline
\end{tabular}

\begin{tabular}{|c|c|c|}
\hline \multicolumn{3}{|l|}{ Mono-regionals } \\
\hline SA-SZ & 9 & 10.5 \\
\hline SA-SU & 4 & 4.7 \\
\hline SU & 2 & 2.3 \\
\hline SA & 2 & 2.3 \\
\hline SU-ZA & 12 & 13.9 \\
\hline SA-SI & 1 & 1.2 \\
\hline \multicolumn{3}{|l|}{ Biregionals } \\
\hline $\mathrm{IT}+\mathrm{ME}$ & 4 & 4.7 \\
\hline SA-SI+SU-ZA & 9 & 10.5 \\
\hline $\mathrm{ME}+\mathrm{SA}$ & 2 & 2.3 \\
\hline $\mathrm{ME}+\mathrm{SA}-\mathrm{SZ}$ & 1 & 1.2 \\
\hline SA-SI+IT & 3 & 3.5 \\
\hline $\mathrm{SA}+\mathrm{IT}$ & 1 & 1.2 \\
\hline \multicolumn{3}{|l|}{ Pluri-regionals } \\
\hline TR & 7 & 8.1 \\
\hline PAN & 4 & 4.7 \\
\hline $\mathrm{NEO}$ & 1 & 1.2 \\
\hline COSMO & 7 & 8.1 \\
\hline PAL & 2 & 2.3 \\
\hline SA-SI+SU-ZA +ME & 1 & 1.2 \\
\hline SA-SI+SU-ZA +IT & 3 & 3.5 \\
\hline $\mathrm{SA}-\mathrm{SI}+\mathrm{SU}-\mathrm{ZA}+\mathrm{ME}+\mathrm{IT}$ & 2 & 2.3 \\
\hline TR+EU+PAN & 1 & 1.2 \\
\hline SI-SA+SU-ZA +IT & 3 & 3.5 \\
\hline $\mathrm{ES}+\mathrm{IT}+\mathrm{ME}$ & 1 & 1.2 \\
\hline SA-SI+SU-ZA +IT+ME+TR & 1 & 1.2 \\
\hline END & 3 & 3.5 \\
\hline Total & 86 & 100 \\
\hline
\end{tabular}

Four hundred and sixteen species are recorded in Hadramout governorate (Al-Khulidi, 2006). Three hundred and eighty five species are recorded from Shabwa governorate (Al-Khulidi, 2013). Also the present results proved that the flora of Kharab AlMarashi is rich in the genera since its genera represent about $6.4 \%$ of the total genera in the whole flora of Yemen (67/1068).

The number of the families of Kharab AlMarashi is constituted about $20.1 \%$ of the total of the families in the flora of Yemen as a whole (36/179). This means that the flora of Kharab AlMarashi is relatively rich in its floristic composition. Thus, it may be owing to the biotic, climatic and topographic factors.

In the flora of Yemen the number of genera in proportion to that of species are 2.7, according to Khulidi (2013). This is very low figure compared with the global average proportion, which are about 13.6 (Good, 1947). The present study indicates that the flora of Kharab AlMarashi goes below the average level of the Yemenis flora where the number of species per genus is 1.3 .

This means that the flora of Kharab AlMarashi is floristically diverse than that of Yemenis flora, as the region that has a certain numbers of species each of which belongs to a different genus is relatively more diverse than that a region with the same number of species but belong to a few number of genera (Hawksworth 1995; Khedr et al., 2002).

The flora of this region is poor in the vascular non flowering plants e.g. Pteridophyta and Gymnospermae. This may be due to that hot climate. The above results agree with the global floral composition (Cronquist, 1981; AlKhuladi, 1989, Westingaan and Thalen, 1980; AlHubaishi and Muller-Hohenstein, 1984).. Thirty six families are recorded: Dicots (32 families) and Monocots (4 families). The number of dicots families represents $88.9 \%$, while the number of the monocots represents $11.1 \%$ of the total number of the recorded families.

At the generic level of the Angiospermae comprise 67 genera. Of these dicots comprise about 63 genera $(94.0 \%)$, while the monocots are represented by 4 genera (5.9\%). The largest families of the dicots are: Asteraceae ( 9 genera, 12 species), Asclepidaceae (5 genera, 6 species), Solanaceae (5 genera, 6 species), Poaceae (5 
genera, 6 species), Malvaceae (4 genera, 4 species), Euphorbiaceae (3 genera, 4 species), Lamiaceae (3 genera, 4 species), Zygophyllaceae (3 genera, 6 species) and Mimosaceae (1 genera, 7 species). Poaceae is the largest family of the monocots ( 5 genera and 6 species).

Regarding the number of taxa belong the families the present results are in agreements with those of (Ghazanfar, 1992; Al-Kulaidi, 2013; AlYemeni, 1999; Al-Wadie, 2002). Succulent plants are of a great ecological significance, particularly in arid and semi-arid parts of Yemen or the Arabian Peninsula in general (Gazanfar, 1992; Wood, 1997). They store water in their stems, leaves or roots, a characteristic feature adopted by several plants to withstand high temperature and low precipitation. Some of the families, which are rich in succulent species, are Asteraceae, Asclepiadaceae, and Euphorbiaceae. The same results are in agreement with those of McCoy (2003) and Zohary (1973).

The succulent habit of the plants may be reflect the dominant climatic factors in this region since plants modify their parts leaves, stems and inflorescences to storage the available water in the wet rainy seasons to survive in the dry seasons. One of the most distinct features of the flora of Yemen is the high percentage of the endemic plants among its components (Al-Hubaishi and MullerHohenstein, 1984; McCoy, 2003; Al-Khulaidi, 2000; Al-Khulaidi, 2010). The present results of the flora of Kharab AlMarashi have revealed the importance of this region in terms of plant biodiversity.

Similarly vegetation is also found in other arid areas where moisture is the main limiting factors for plant growth. For example, some species that are common in the study area such as Panicum turgidium, Fagonia indica, Rhaza stricta and Aerva javanica are also restricted to wadi beds and the sands of the north-eastern and eastern desert areas of Yemen (e.g. Marib and Rada'a) and the deserts of Oman (Gazanfar, 1992).

Similar vegetation is also found in other arid areas where moisture is the main limiting factor for plant growth. For example, some species that are common in the study area such as Panicum turgidum, Fagonia indica, Rhazya stricta and Aerva javanica are also restricted to wadi beds and the sands of the north-eastern and desert areas of
Yemen (e.g. Marib and Rada'a) and the deserts of Oman (Gazanfar, 1992).

The life form spectra the study area (Karab AlMarashi) indicated that, Chamaephytes had the highest contribution. These results agree with Hamood (2012) and Al-Sodany et al. (2014)and disagree with Mosallum (2007), Abd El-Ghani et. al. (2013), Heneidy and Bidak (2001) and El Demerdash et al. (1995) in the rest elements of life forms. Chamaephytes life form is able to withstand water logging high salinity levels and a wide range of temperature variability (Beeftink, 1977; Zahran, 1982).

The life forms spectrum is thought to be either hereditary adjustment to environment or representing the residual effect of some historical, climatic or biotic condition on the plant population Waisel (1972). In the present study, the Chamaephytes are the most dominant life forms in the studied area. They are represented by 36 species which constitute about $40.9 \%$ of the total recorded species. These are followed by the Phanerophytes (22 species, 25.9\%) and Therophytes (16 species, 18.6\%) of the total recorded species. The dominance of the Chamaephytes life form and the short life cycles plants (Therophytes) may be attributed to be response to the hot dry climate, topographic variation and biotic influence.

In the neighbor countries such as Taif of Saudi Arabia Mosallum (2007) reported that the dominant life forms of that region are Therophytes and Chamarphytes while El-Ghanem et al. (2010)reported the same results from Hail region of Saudi Arabia. From the Mediterranean deltic Lake (Lack Burollos) of Egypt Khedr (1999) reported that the dominant life forms in the that area are Therophytes, Cryptophytes, Chamaephytes, phanerophytes and Hemicryptophytes. The Chamaephytes, Crypptophytes and Hemicryptophytes are playing an important role in the processes of sand accumulation and succession of vegetation. In the study area plants of these three life forms have the ability to act as barriers to wind and /or water borne materials which are then deposited around them. This enables is such plants to produce adventitious roots and aerial shoots from their buried organs and to replace them when they die. 
Appendix List of plant species recorded in the study area with their family name, life forms and chorotype. Chorptypes: SA=Saharo-Arabian; SU-ZA=Sudano-Zambezian; SA-SZ=Saharo-Sudano-Zambezian; SU=Sudano; TR=Tropical; IT=Irano-Truranian; ME=Meditrranean; PAN=Panotrpical; NEO=Neotropical; SA-SI=SaharoSindian; Eu=Europian; ES= Europ - Siberian; $\mathrm{COSMO} \mathrm{=} \mathrm{Cosmopoplitan;} \mathrm{END+=Endemic.}$

\begin{tabular}{|c|c|c|c|}
\hline Family & Scientific name & Life form & Chorotype \\
\hline \multirow[t]{3}{*}{ Amaranthaceae } & Achyranthes aspera $\mathrm{L}$. & Therophytes & $\mathrm{IT}+\mathrm{ME}$ \\
\hline & Aerva javanica (Burn.f.) Juss.ex Schult & Chemaephytes & $\mathrm{TR}$ \\
\hline & Aerva lanata (L.)Juss.exSchult. & Chemaephytes & TR \\
\hline Apocynaceae & Rhazya stricta Decne & Chamaephytes & $\mathrm{SA}+\mathrm{SZ}$ \\
\hline \multirow[t]{5}{*}{ Asclepiadaceae } & Calotropis procera (Ait.) Ait.f. & Phanerophytes & $\mathrm{SA}+-\mathrm{SZ}$ \\
\hline & Caralluma penicellata (Defl.) N.E.Br. & Chamaephytes & $\mathrm{END}^{+}$ \\
\hline & Monolluma quadrangula (Forssk.) N.E.Br. & Chamaephytes & $\mathrm{END}^{+}$ \\
\hline & Desmidorchis retrospiciens Ehrenb. & Phaneraphytes & $\mathrm{SA}+\mathrm{SU}$ \\
\hline & Leptadenia pyrotechnica (Forssk.) Decne & Phaneraphytes & $\mathrm{SA}+\mathrm{SU}$ \\
\hline Boraginaceae & $\begin{array}{l}\text { Heliotropium longiflorum (A.DC.) Steud. } \\
\text { Hochst.ex Bunge. }\end{array}$ & Chamaephytes & $\mathrm{SA}+\mathrm{SZ}$ et \\
\hline \multirow[t]{3}{*}{ Caesalpiniaceae } & Senna italica (Mill). & Hemicryptophytes & $\mathrm{SA}+\mathrm{SZ}$ \\
\hline & Senna occidentalis ( L.)Link. & Chamaephytes & PAN \\
\hline & Tamarindus indica $\mathrm{L}$. & Phnareophytes & PAL \\
\hline \multirow[t]{3}{*}{ Capparaceae } & Capparis cartilaginea Decne. & Chamaephytes & SU \\
\hline & Capparis spinosa $\mathrm{L}$. & Chamaephytes & $\mathrm{IT}+\mathrm{ME}$ \\
\hline & Dipterygium glaucum Decne. & Therophytes & SA-SI+SU-ZA \\
\hline Casuarinaceae & Casuarina equisetifolia $\mathrm{L}$. & Phanaerophytes & $\mathrm{TR}$ \\
\hline Celasteraceae & Catha edulis Forssk. & Phanaerophytes & TR \\
\hline Chenopodiaceae & Suaeda monica Forssk.exJ.F.Gmel. & Chamaephytes & $\mathrm{SA}+\mathrm{SZ}$ \\
\hline Cleomaceae & Cleome brachycarpa Vahl.ex DC. & Chamaephytes & $\mathrm{SA}$ \\
\hline \multirow[t]{11}{*}{ Asteraceae } & Atractylis carduus (Forssk.) C.Chr. & Hemicryptophytes & $\mathrm{ME}+\mathrm{SA}$ \\
\hline & Conyza bonariensis (L.) Cornquist. & Therophytes & $\mathrm{NEO}$ \\
\hline & Helianthus annus L. & Chamaephytes & $\mathrm{SA}+\mathrm{SZ}$ \\
\hline & Kleinia odora (Forssk,)DC. & Chamaephytes & $\mathrm{SU}+\mathrm{ZA}$ \\
\hline & Pulicaria jaubertii Gamal- Eldin. & Chamaephytes & SA- SI+SU-ZA \\
\hline & Pulcaria crispa (Cass.)Oliv.\&Hiem & Chameaphytes & $\mathrm{SA}+\mathrm{SZ}$ \\
\hline & Pulicaria undulata (L.)C.A.Mey. & Chamaephytes & $\mathrm{SA}+\mathrm{SU}$ \\
\hline & Tagetes erecta $\mathrm{L}$. & Therophytes & COSM \\
\hline & Tagetes minuta $\mathrm{L}$. & Therophytes & COSM \\
\hline & Reichardia tingitana (L.)Roth. & Therophytes & $\mathrm{ME}+\mathrm{SA}+\mathrm{SZ}$ \\
\hline & $\begin{array}{l}\text { Verbesina encelioides (Cav.) Benth \& Hook. } \\
\text { fil ex A.Gray. }\end{array}$ & Therophytes & TR \\
\hline Convolvulacrae & Conolvulus arvensis L. & Hemicryptophytes & TR \\
\hline \multirow[t]{3}{*}{ Cucurbitaceae } & Citrullus colocynthis ( L.) Schrad. & Hemicryptophytes & $\mathrm{ME}+\mathrm{SA}$ \\
\hline & Cucumis prophetarum Juus. & Hemicryptophytes & $\mathrm{SA}+\mathrm{SU}$ \\
\hline & Momordica balsamina $\mathrm{L}$. & Therophytes & PAN \\
\hline \multirow[t]{2}{*}{ Brassicaceae } & Diplotaxis harra (Forssk.)Boiss. & Therophytes & SA-SI+IT \\
\hline & Schouwia purpurea (Forssk.) Schweinf. & Therophytes & SA-SI+IT \\
\hline Cyperaceae & Cyperus laevigatus L. & Hemicryptophytes & PAN \\
\hline \multirow[t]{4}{*}{ Euphorbiaceae } & Euphorbia prostrate Ait. & Therophytes & COSM \\
\hline & Jatropha pelargoniifolia Courb. & Chameophytes & SU-ZA \\
\hline & Jatropha spinosa (Forssk.)Vahl. & Chamaephytes & SU-ZA \\
\hline & Ricinus communis $\mathrm{L}$. & Phanerophytes & COSM \\
\hline Papilionaceae & Medicago sativa $\mathrm{L}$. & Chamaephytes & COSN \\
\hline \multirow[t]{3}{*}{ Poaceae } & Pennisetum glaucum (L.) R.Br. & Hemicryptophytes & PAL \\
\hline & Pennisetum villosum R.Br.ex Fresen. & Hemicryptophytes & $\mathrm{TR}$ \\
\hline & Cynodon dactylon ( L.) Pers. & Hemicryptophytes & COSM \\
\hline Lamiaceae & Lavandula pubescens Decne & Chamaephytes & $\mathrm{SA}+\mathrm{SI}+\mathrm{SU}-\mathrm{ZA}+\mathrm{ME}$ \\
\hline
\end{tabular}




\begin{tabular}{|c|c|c|c|}
\hline & Leucas inflata Benth. & Chamaephytes & SA-SI+SU-ZA \\
\hline & Ocimum basilicum $\mathrm{L}$. & Chamaephytes & SU-ZA \\
\hline & Ocimum filamentosum Forssk. & Chamaephytes & SU-ZA \\
\hline \multirow[t]{4}{*}{ Malvaceae } & Abutilon fruticosum Guill.\&Perr. & Chamaephytes & $\mathrm{SA}+\mathrm{SZ}$ \\
\hline & Malva parviflora $\mathrm{L}$. & Therophytes & ME+ IT \\
\hline & Hibiscus purpureus Forssk. & Chamaephytes & SU-ZA \\
\hline & Gossypium arboretum $\mathrm{L}$. & Phanerophytes & SA-SI \\
\hline \multirow[t]{7}{*}{ Fabaceae } & Acacia asak (Forssk.)Willd. & Phanerophytes & SA-SI+SU-ZA \\
\hline & Acacia ehrenbergiana Hayne. & Phanerophytes & SU-ZA \\
\hline & Acacia etbaica Schweinf. & Phanerophytes & SU-ZA \\
\hline & Acacia mellifera (Vahl) Benth. & Phanerophyte & SA-SI+SU-ZA \\
\hline & Acacia oerfota (Forssk.) Schweinf. & Phanerophytes & SA-SI+SU-ZA \\
\hline & Acacia seyal Del. & Phanerophytes & $\mathrm{SA}+\mathrm{SZ}$ \\
\hline & Acaia tortilis (Forssk.)Hayne. & Phanerophytes & SA-SI+SU-ZA \\
\hline Moraceae & Ficus carica $\mathrm{L}$. & Phanerophytes & $\mathrm{IT}+\mathrm{ME}$ \\
\hline Myrtaceae & Eucalyptus rostorata $\mathrm{L}$. & Phanerophytes & TR+EU+PAN \\
\hline \multirow[t]{2}{*}{ Nyctaginaceae } & $\begin{array}{l}\text { Commicarpus heleinae (J.A.Schultes) } \\
\text { Meikle. }\end{array}$ & Chamaephytes & SA-SI+SU-ZA+IT \\
\hline & Commicarpus plumbagineus (Cav.) Standl. & Chamaephytes & SU-ZA \\
\hline Orobanchaceae & Cistanche phelypaea (L.) Cout. & Parasite & SA-SI+SU-ZA+ME+IT \\
\hline Palmaeae & Phoenix dactylifera $\mathrm{L}$. & Phanerophytes & $\mathrm{SA}+\mathrm{SI}+\mathrm{IT}$ \\
\hline Resedaceae & Reseda sphenocleoides Defl. & Chamaephytes & $\mathrm{END}^{++}$ \\
\hline Rhamanacea & Ziziphus spina-christi (L.) Willd & Phanerophytes & SA-SI+SU-ZA+IT+ME \\
\hline Salvadoracaeae & Salvadora persica (L.) & Phanerophytes & SU-ZA \\
\hline \multirow[t]{6}{*}{ Solanaceae } & Capsicum frutescens $\mathrm{L}$. & Chamaephytes & SI-SA+SU-ZA+IT \\
\hline & Lycospersicum esculentum Miller. & Chamaephytes & SI-SA+SU-ZA+IT \\
\hline & Lycium shawii Roem \& Schult. & Phanerophytes & $\mathrm{SI}-\mathrm{SA}+\mathrm{SU}-\mathrm{ZA}+\mathrm{IT}$ \\
\hline & Solanum incanum $\mathrm{L}$. & Chamaephytes & SU-ZA \\
\hline & Solanum villosum Miller & Therophytes & $\mathrm{ES}+\mathrm{IT}+\mathrm{ME}$ \\
\hline & Withania somnifera (L.) Dunal. & Chamaephytes & SA-SI+SU-ZA+IT+ME+TR \\
\hline Tamaricaeae & Tamarix aphylla (L.) G.Karst. & Phanerophytes & SA-SI+SU-ZA+ME+IT \\
\hline Tiliaceae & Grewia tenax (Forssk.) Fiori & Phanerophytes & SA-SI+SU-ZA+IT \\
\hline Typhaceae & Typha domingensis (Pers) Poir,ex Steud. & Chamaephytes & PAN \\
\hline Apiaceae & Anethum graveolens $\mathrm{L}$. & Therophytes & SU-ZA \\
\hline Utricaceae & Forsskaolea tenacissima $\mathrm{L}$. & Hemicryptophytes & SA-SI+SU-ZA \\
\hline \multirow{5}{*}{ Zygophyllaceae } & Fagonia bruguieri DC. & Chamaephytes & $\mathrm{SA}+\mathrm{IT}$ \\
\hline & Fagonia indica Burm.f. & Chamaephytes & SA-SI+SU-ZA+IT \\
\hline & Peganum harmala $\mathrm{L}$. & Geophytes & COSM \\
\hline & Zygophyllum coccinium $\mathrm{L}$. & Therophytes & SA \\
\hline & Zygophyllum simplex $\mathrm{L}$. & Therophytes & SA-SI+SU-ZA+ME+IT \\
\hline
\end{tabular}

\section{Acknowledgment}

Deep thanks to student Hanna Daakan, Botany section, Biology Department, Faculty of Sana'a University, for helping me with collection of the species from the study area.

\section{References}

Abd El-Ghani MM Salma F Salem BA (2013) El-
Hadidy, M. Abdel-Aleem, Biogeographical relations of a hyper arid desert flora in eastern Egypt. African Journal of Ecology 52: 173-191.

Al-Hubaishi AA Muller-Hohenstein K (1984) An Introduction to the vegetation of Yemen: Ecological basis, floristic composition and human influence. Published by Deutsche Gesellschaft Technische Zusammenarbeit (GTZ), Eschborn, West Germany, $209 \mathrm{pp}$

Al-Khuladi AA (2006) Environmental and human determinates of vegetation distribution in the Hadramaut region, Republic of Yemen. A thesis 
submitted for the degree of Doctor of Philosophy School of GeoScience University of Edinburgh.U.K,413 pp

Al-Khulaidi AA (1989) A comparative vegetation survey of four photographic regions in the Y.A.R. unpublished M.Sc. thesis, ITC, Enschede, The Netherlands

Al-Khulaidi AA (2000) Flora of Yemen. (SEMP, YEM/97/100) EPC, Sana'a, Yemen, 200 pp

Al-Khulaidi AA (2010) The vegetation of the Hadhramout. Abstracts Compendium of Seventh Scientific Conference of the Yemeni Biological Society, Sana'a.Yemen, 440 pp

Al-Khulidi AA (2013) Flora of Yemen. Ministry of water and Environment, Sustainable natural resource, Management project (SNRMP)11, 402 pp

Al-Sodany YM Hosny AM Al-Yasi HM (2014) Floristic Diversity and plant communities associated with Juniper forests in high altitudes, International Journal of current life Sciences, research article (Available online at//www.bretj.com), 4: 118-133.

Al-Wadie H (2002) Floristic composition and vegetation of Wadi Talha, Aseer Mountains, south west Saudi Arabia. Online J. Biological Sci., 2: 285288.

Al-Yemeni MN (1999) A check list of weeds in AlKharj area of Saudi Arabia. Pak. J. Bio. Sci., 2: 713.

Beeftink WG (1977) The coastal salt marshes of western and northern Europe. In: Ecosystems of the world 1.pp.109-155.Chapman V.J.(ed.), Elsevier, Amsterdam

Boulos L (2002) Flora of Egypt.Vol.3,Al-Hadra publishing , Cairo,Egypt,617 pp

Chaudhary SA (1989) Grasses of Saudi Arabia. National Herbarium National Agriculture and Water Research Center, Ministry of Agriculture and Water, Riyadh, Kingdom of Saudi Arabia, 465 pp

Chaudhary SA (1999) Flora of the Kingdom of Saudi Arabia illustrated. Vol. 1, National Herbarium, National Agriculture and Water Research Center, Ministry of Agriculture and Water, Riyadh, Kingdom of Saudi Arabia, 692 pp

Chaudhary SA (2000) Flora of the Kingdom of Saudi Arabia illustrated. Vol.2 (3), National Herbarium, National Agriculture and Water Research Center, Ministry of Agriculture and Water, Riyadh, Kingdom of Saudi Arabia, 432 pp

Chaudhary SA (2001a) Flora of the Kingdom of Saudi Arabia illustrated. Vol.2 (1), National Herbarium, National Agriculture and Water Research Center, Ministry of Agriculture and Water, Riyadh, Kingdom of Saudi Arabia, 675pp

Chaudhary SA (2001b) Flora of the Kingdom of Saudi Arabia illustrated. Vol.2 (2), National Herbarium, National Agriculture and Water Research Center,
Ministry of Agriculture and Water, Riyadh, Kingdom of Saudi Arabia, 542 pp

Chaudhary SA (2001c) Flora of the Kingdom of Saudi Arabia illustrated. Vol. 3, National Herbarium, National Agriculture and Water Research Center, Ministry of Agriculture and Water, Riyadh, Kingdom of Saudi Arabia, 368 pp

Chaudhary SA Revri, R (1983) Weeds of North Yemen. Deutsche Gesellschaft für Technische Zusammenarbeit (GTZ) GmbH, German, 411 pp

Collenette S (1999)Wild flowers of Saudi Arabia (2).National Commission for Wildlife Conservation and Development, Riyadh, Saudi Arabia,799 pp

Cronquist A (1981) An integrated system of classification of flowering plants. Columbia Univ. Press, New York, NY, USA

El Demerdash MA Hegazy AK Zilay AM (1995) Vegetation-soil relationships in Tihamah coastal plains of Jazan region, Saudi Arabia. J Arid Environ 30: 161-174.

El-Ghanem WA Galal TM Badr A (2010) Floristic composition and vegetation analysis in Hail L.M, region north of central Saudi Arabia. Journal of Biological Sciences 17: 119-128.

Fosberg FR Sachet M (1965) Manual for Tropical Herbaria. International Bureau for plant taxonomy and nomenclature, Utrecht, Netherlands,

Ghazanfar SA (1992) Quantitative and biogeographic analysis of the flora of the Sultanate of Oman. Global Ecology Biogeography letters, 2: 189-195.

Good R (1947) Geography of the flowering plants. $1^{\text {st }}$ .ed., Longmans, London, 403p

Hamood OSS (2012) Flora of Toor Al-Baha district, Laheg Governorate, Republic of Yemen and Its Phytogeographical affinities, Ph.D. Thesis, Sana'a University, Faculty of Science, Biology Department, Botany Section, 260pp

Hawksworth DL (1995) Biodiversity: measurement and estimation. Chapman and Hall, London 140 pp

Heneidy SZ Bidak LM (2001) Multipurpose plant species in Bisha, Asir region, Southwestern Saudi Arabia.J.KingSoud.Univ.,13: 11-26.

Khedr AA (1999) Floristic composition and Phytogeography in Mediterranean deltaic Lake (Lake Burollous), Egypt, ecologia mediterranea, 25: 1-11.

Khedr AA Cadotte MW El-Keblawy A Loveti-Doust J (2002) Phytogentic diversity and ecological feature in the Egyptian flora. Biodiversity and Conservation, 11: 1809-1824.

McCoy TA (2003) Rhytidocaulon splendidum McCoy A new species from southwestern Yemen. Cact. and Succ. J. (U.S.), 75: 154-157.

Migahid AM (1978) Flora of Saudi Arabia. Vol. 1 \& 2, Riyadh University

Miller AG (1991) Nyberg, J.A. Patterns of endemism in 
Arabia. Fl. Veg. Mundi, 9: 263-279.

Ministry of water and Environmental, Fourth national report(2010) Assessing Progress towards Target-the $4^{\text {th }}$ national CBD report July, 2009. Environment protection Authority, Ministry of water and environment, Republic of Yemen, pp100

Mosallum HA (2007) Comparative study on the vegetation of protected and non-protected areas, Sudera, Taif, Saudi Arabia. International Journal of Agriculture and Biology, 9: 202-214.

Omar SAS (2000) Vegetation of Kuwait, Arid land Agriculture Department Food Resources Division, Kuwait for Institute for Scientific Research, First Edition, Kuwit,159pp

Raunkiaer C (1937) The plant life forms and statistical plant Geography. Oxford University, Clarendon press, $162 \mathrm{pp}$

Results of the general census of population and housing facilities(2004) Statistical Department Central planning Organization, Prime Minister's office, Yemen Republic

Tackholm, V (1974) Students flora of Egypt, $2^{\text {nd }}$ Cairo University Publications, Cooperative printing company, Beirut, 888pp

Waisel Y (1972) Biology of halophytes. Academic Press, New York, pp.395

Westinga E Thalen DC (1980) A survey and problem analysis of the rangelands in the Rada district RIRDP technical note 5. Ministry of Agriculture and Forestry, Yemen

Wickens GE (1978) The flora of Jebel Marra (Suda Republic )and its geographical affinities. Kew Bulletin Additional Series 5-385.

Womberley JS (1981) Plant collecting and herbarium development (a manual). Food and Agriculture Organization of the United Nations (FAO), Rome

Wood J R I (1997) A handbook of the Yemen flora. Royal Botanic Gardens, Kew, UK, 434 pp

Zahran MA (1982) Ecology of the halophytic vegetation of Egypt. Tasks for vegetation science, vol.2 ed. by D.N.Sen and K.S. Rajpurohit. Dr. W. Junk publisher. pp. 3 - 20. The Hague

Zohary M (1973) Geobotanical foundations of the Middle East. Gustav Fischer Verlag Vols 1\&2, Stuttgart, W. Germany

\section{الملخص العربى \\ دراسة على فلورا اليمن. فلورا الحياة التباتية في مديرية خراب المراشي ، محافظة الجوف، اليمن \\ جامعة صحمداء ـ ـ كلية العلوم ـ قسم علوم الحياة ـ شعبة النبات}

تهاف هذه الدراسة إلى معرفة الحياة النباتية في مديرية خراب المراثي ، محافظة الجوف، اليمن. تناولت التئل

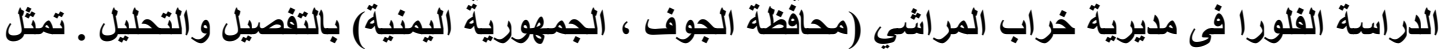

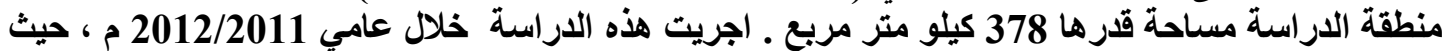

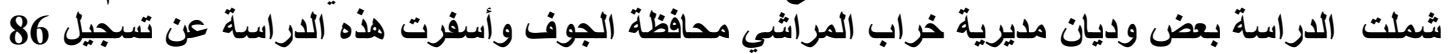

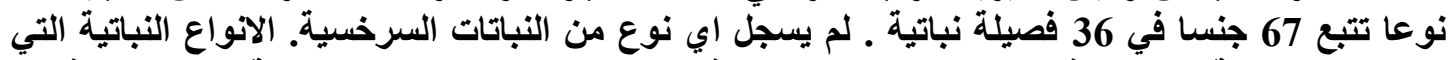

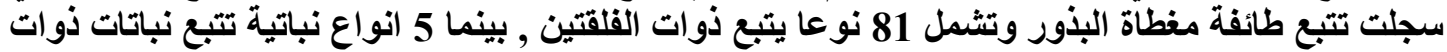

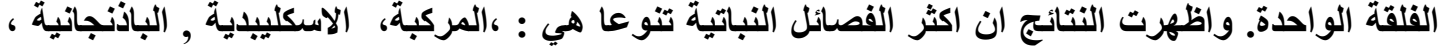

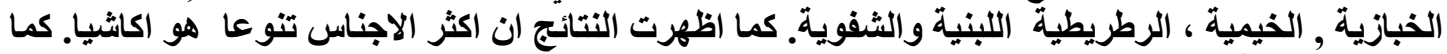

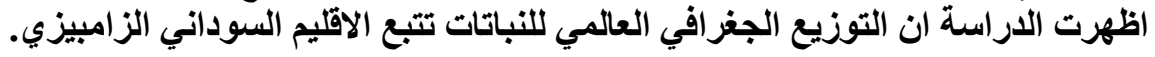

